Canadian Science Publishing

Canadian Journal of Earth Sciences Revue canadienne des sciences de la Terre

\title{
Upper Middle to lower Upper Ordovician chitinozoans and conodonts from the Bliudziai-150 core, southern Lithuania
}

\begin{tabular}{|r|l|}
\hline Journal: & Canadian Journal of Earth Sciences \\
\hline Manuscript ID & cjes-2015-0205.R2 \\
\hline Manuscript Type: & Article \\
\hline Date Submitted by the Author: & 22-Feb-2016 \\
\hline Complete List of Authors: & $\begin{array}{l}\text { Stouge, Svend; Geological Museum } \\
\text { Bauert, Garmen; Tallinn University of Technology, Institute of Geology } \\
\text { Bauert, Heikki; Tallinn University of Technology, Institute of Geology } \\
\text { Nõlvak, Jaak; Tallinn University of Technology, Institute of Geology } \\
\text { Rasmussen, Jan A.; Geological Survey of Denmark and Greenland }\end{array}$ \\
\hline Keyword: & Chitinozoans, Conodonts, Ordovician, Biostratigraphy, Lithuania \\
\hline & \multicolumn{2}{|l}{} \\
\hline
\end{tabular}


Upper Middle to lower Upper Ordovician chitinozoans and conodonts from the Bliudziai-150 core, southern Lithuania

\section{Svend Stouge $^{1}$, Garmen Bauert ${ }^{2}$, Heikki Bauert ${ }^{2}$, Jaak Nõlvak ${ }^{2}$ and Jan A. Rasmussen ${ }^{1}$}

1 Natural History Museum of Denmark, University of Copenhagen

Øster Voldgade 5-7, DK-1350 Copenhagen; e-mails: svends@snm.ku.dk;

janr@snm.ku.dk

2 Institute of Geology at Tallinn University of Technology, Ehitajate tee 5, Tallinn 19086,

Estonia; e-mails: garmen.bauert@ttu.ee, baltoscandia@yahoo.com,

jaak.nolvak@ttu.ee

Correspondance

Svend Stouge

Natural History Museum of Denmark

Geological Museum, University of Copenhagen

Østervoldgade 5-7, DK-1350 Copenhagen; phone: +45 353-22358

e-mail: svends@snm.ku.dk 


\begin{abstract}
Integration of chitinozoan and conodont biozones is based on detailed collections from the Bliudziai-150 well, southern Lithuania that penetrated upper Darriwilian - lower Sandbian sedimentary carbonate rocks. The strata accumulated at the southeastern side of the Livonian Tongue and represent the transition from shallow shelf facies of the Lithuanian shallow-water shelf facies belt to the deeper-water shelf facies belt. Systematically collected and closely spaced samples of the carbonates from the Bliudziai-150 core yielded both chitinozoans and conodonts in abundance. The chitinozoans are assigned to the Laufeldochitina striata, Laufeldochitina stentor, Angochitina curvata-Armoricochitina granulifera, Lagenochitina dalbyensis, Belonechitina hirsuta and Spinachitina cervicornis chitinozoan biozones and the conodonts to the Pygodus serra Zone (with three subzones), Pygodus anserinus Zone (with two subzones) and the three subzones of the Amorphognathus tvaerensis Zone.
\end{abstract}

The fossils are clearly of Baltoscandian affinity and the integrated results support existing knowledge concerning the biostratigraphy of the two groups in Baltoscandia. Thus, the studied interval is confidently assigned to the Lasnamägi, Uhaku, Kukruse and Haljala regional stages of the East Baltic regional chronostratigraphical scheme, corresponding to the global upper Darriwilian - lower Sandbian stages (Middle to Upper Ordovician). International correlation of the chitinozoan and conodont succession is presented and the position of the base of the international Sandbian Stage is placed at $1380.00 \mathrm{~m}$ in the Bl-150 core. A horizon marked by multiple discontinuity surfaces represents the base of Kegel depositional sequence and coincides with the appearance of Armoricochitina granulifera, Angochitina curvata, Lagenochitina dalbyensis and Baltoniodus gerdae in the B1-150 core. 
Keywords: Chitinozoans, Conodonts, Ordovician, Biostratigraphy, Lithuania.

\section{Introduction}

Chitinozoans and conodonts are two well-established microfossil groups that are used extensively for biostratigraphical evaluations and correlations, especially in the upper Middle to Upper Ordovician of the Baltoscandian region of northern Europe (e.g. Bergström 1971; Dzik 1978; Grahn 1984; Nõlvak and Grahn 1993; Nõlvak and Bauert 2006; Grahn and Nõlvak 2010; Zhang 1998; Saadre et al. 2004; Viira 2008, 2011; Viira et al. 2006; Hints et al. 2012; Männik and Viira 2012). This paper presents the faunal succession from the little known Bliudziai-150 core section in southern Lithuania located on the eastern flank of the Livonian Tongue (Laskov et al. 1981; Laskovas 2000). The study is based on direct evidence and high-resolution integration of chitinozoan - conodont biostratigraphy for upper Middle and lower Upper Ordovician. It provides close ties with the Ordovician chitinozoan and conodont biozonations characteristic for the regional Lasnamägi to Haljala stages and correlation to the international Middle to Upper Ordovician series boundary in carbonate facies.

\section{Geological setting, stratigraphy and material}

During the Ordovician the Baltoscandian platform, west of present-day Moscow, was covered by an intracratonic sea and mostly carbonate rocks were deposited in this large area. The Ordovician epicontinental sea was connected to the offshore deeper-water environment with fineclastic sediments in the northwest and southwestern Caledonides (Fig. 1). The Ordovician succession of the study area accumulated on the eastern flank of the Livonian Tongue composed of 
marine limestone, marl, minor siltstone and organic-rich shale that were deposited on the shelf during several transgressive-regressive cycles and in a shallow to moderately deep-water setting.

The Bliudziai-150 well (N55¹5'16.056", E2257'59.976") was drilled near Šimkaičiai in southern Lithuania, approximately $165 \mathrm{~km}$ west to northwest of Vilnius (Fig. 1). The investigated 22 m long interval (1391 to 1369 m; Fig. 1) constitutes the Daugavpils Group, subdivided into three formations: in ascending order, the Vyžūnai (1391.91 to 1383.15 m), Krastai and Kriaunos formations (1383.15 to $1973.90 \mathrm{~m}$ ) and the two stratigraphically succeeding Sartai and Šventupys formations (from $1373.90 \mathrm{~m}$ ), which are the two lower formations of the Mezciews Group (Laskovas 2000; Fig. 1). The boundary between the Kriaunos and Sartai formations is prominent and the series of closely spaced discontinuity surfaces with phosphatic impregnations is characteristic for the upper beds of the Kriaunos Formation. The numerous discontinuity surfaces indicate an irregular character of sediment accumulation.

The 53 closely spaced to nearly bed-by-bed samples were collected and processed for both chitinozoans and conodonts in the interval ranging from $1390.92 \mathrm{~m}$ to $1369.07 \mathrm{~m}$, covering the Lasnamägi, Uhaku, Kukruse and Haljala regional stages. All samples were productive for conodonts, but the samples from the lowermost (1390.92 $\mathrm{m}$ to $1390.07 \mathrm{~m}$ ) and middle portions (1387.89 m to $1384.25 \mathrm{~m}$ ) of the Vyžūnai Formation consisting of red to interbedded green limestone were barren of chitinozoans.

\section{Biostratigraphy of the Bliuziai-150 core}

The chitinozoan fauna is of high diversity in terms of number of species, but the degree of preservation is poor to moderate (i.e. the observed chitinozoan vesicles are rather brittle 
and often broken into pieces). The conodont fauna is moderately diverse, and of reasonable abundance. The CAI value is approximately 1.5 of Epstein et al. (1977), and up-section the preservation declines from fine to good (often broken specimens). Altogether 47 chitinozoan species from 16 genera and 23 genera and 41 conodont species have been identified from the studied upper Darriwilian - lower Sandbian succession. The ranges of the biostratigraphically significant chitinozoan and conodont species are given in Figure 1 and illustrated in Figures 2 and 3.

REPOSITORY: All illustrated chitinozoan specimens are hosted at Institute of Geology at Tallinn University of Technology (GIT nos. 726-1 - 726-10). The figured conodont specimens are kept at the micropaleontological collections of the Natural History Museum of Denmark, University of Copenhagen, Denmark (MUGH nos. 31429-31453).

\section{Chitinozoan biozones}

The chitinozoan taxonomy used here follows that of Paris et al. (1999) and the chitinozoan zones are after Nõlvak and Grahn (1993). Chitinozoans with short temporal ranges are well known from the Darriwilian-Sandbian succession of the Estonian and Swedish sections of Baltoscandia (e.g. Grahn 1984; Nõlvak et al. 1999; Nõlvak and Bauert 2006; Grahn and Nõlvak 2010; Tammekänd et al. 2010).

The lowest chitinozoan zone in the studied Bliudziai-150 section is the Laufeldochitina striata Zone (interval 1389.91 to $1380.70 \mathrm{~m}$ ). However, the Conochitina clavaherculi and Conochitina tuberculata Subzones of Nõlvak and Grahn (1993) have not been recognized due to the poor preservational potential of chitinozoans in oxidized red limestone (e.g. Fig. 1). Other 
species, characteristic to the Laufeldochitina striata Zone, are Tanuchitina tallinnensis, Belonechitina pellifera and Cyathochitina sebyensis.

The Laufeldochitina striata Zone is directly followed by the Laufeldochitina stentor Zone, which is recorded from the Krastai-Kriaunos formations. The characteristic chitinozoan species for the Laufeldochitina stentor Zone includes (in order of FAD) Eisenackitina rhenana, Conochitina savalaensis, Belonechitina intonsa, Conochitina viruana, Laufeldochitina aff. striata, Cyathochitina giraffa and Conochitina tigrina. The Sartai and Šventupys formations comprise four temporally short chitinozoan zones (Nõlvak and Grahn 1993) all of which have been established in the Bliudziai-150 section. Angochitina curvata and Armoricochitina granulifera are the oldest zonal chitinozoans, both of which are recorded in one sample and thus form a the joint A. curvata - A. granulifera chitinozoan Zone in the Sartai Formation. The following Lagenochitina dalbyensis Zone includes the temporally limited species Belonechitina jaanussonii. The stratigraphical extent of the Belonechitina hirsuta Zone is not well confined in this section as the zonal species is recorded in only one sample. The Spinachitina cervicornis Zone is the uppermost chitinozoan zone recorded in the Bliudziai-150 core.

\section{Conodont biozones}

The conodont zones of Bergström (1971, 1983, 2007a, b) with additions by Dzik (1978, 1994) and Zhang (1998) are here used as reference. The conodonts are amber coloured. The fauna is clearly of Baltoscandian affinity i.e. belonging to the North Atlantic conodont province typical of Baltica. 
The investigated Ordovician deposits of the Bliudziai-150 core are assigned to the Pygodus serra Zone with the Baltoplacognathus reclinatus, Baltoplacognathus robustus and Eoplacognathus lindstroemi subzones (the Yangtzeplacognathus foliaceus Subzone has not been investigated in this study), the Sagittodontina kielcencis and Amorphognathus inaequalis subzones of the Pygodus anserinus Zone and Baltoniodus variabilis, Baltoniodus gerdae and Baltoniodus alobatus subzones of the Amorphognathus tvaerensis Zone.

Pygodus serra is recorded from $1389.19 \mathrm{~m}$ to $1384.55 \mathrm{~m}$ and within the Vyžūnai Formation, but it is probable that the full range of this taxon was not detected here. Baltoniodus prevariabilis and Sagittodontina kielcensis are common associated species. First occurrence (FO) of Triangulodus alatus is at $1390.70 \mathrm{~m}$ and ranges continuously to $1388.12 \mathrm{~m}$, and last occurrence (LO) is at $1381.48 \mathrm{~m}$. Periodon aculeatus is only present in the lowest sample. These taxa are associated with Cornuodus longibasis, Dapsilodus viruensis, Decoriconus pesequus, Costiconus ethingtoni, Drepanoistodus spp. A, Drepanoistodus? balticus, Drepanodus arcuatus s.l., Drepanodus cf. D. robustus, Oslodus semisymmetricus, Panderodus sulcatus, Protopanderodus graeai and Semiacontiodus longicostatus.

The Baltoplacognathus reclinatus Subzone is the second lowest recorded subzone of the Pygodus serra Zone; it extends from $1390.92 \mathrm{~m}$ to $1388.40 \mathrm{~m}$. Few specimens of Yangtzeplacognathus foliaceus from the underlying Yangtzeplacognathus foliaceus Subzone are observed in the lowest investigated sample (i.e. 1390.92 to $1390.76 \mathrm{~m}$ ). The following Baltoplacognathus robustus Subzone is recorded from $1388.40 \mathrm{~m}$ to $1384.98 \mathrm{~m}$ within the Vyžūnai Formation (Fig. 1). This same interval is characterized by the consistent presence of Triangulodus alatus and FO of Protopanderodus varicostatus is at $1388.40 \mathrm{~m}$. The FAD of Eoplacognathus lindstroemi is at $1384.79 \mathrm{~m}$ and it ranges up to $1382.71 \mathrm{~m}$, meaning that the Eoplacognathus lindstroemi Subzone is recorded in the top of the Vyžūnai Formation and the lower part of the 
Krastai Formation. The FAD of Eoplacognathus lindstroemi is accompanied by Yangtzeplacognathus protoramosus (late form) and Phragmodus polonicus, both of which are present only at this single level.

The FAD of Pygodus anserinus is at $1384.25 \mathrm{~m}$ and LAD at $1379.05 \mathrm{~m}$. The former level marks the base of the P. anserinus-Saggitodontina kielcensis Subzone. The transition from Baltoniodus prevariabilis to Baltoniodus variabilis is observed in this subzone. Protopanderodus cf. liripipus appears at $1382.07 \mathrm{~m}$, which is slightly above the base of the Krastai Formation. The fauna continues unchanged until $1378.87 \mathrm{~m}$ i.e. to the formational boundary of the Krastai and Kriaunos formations. The Sagittodontina kielcensis Subzone extends from the base of the Pygodus anserinus Zone at $1384.25 \mathrm{~m}$ to FAD of Amorphognathus inaequalis at $1381.25 \mathrm{~m}$.

The base of the A. inaequalis Subzone is at $1381.25 \mathrm{~m}$. The species is consistently present in the succeeding samples, but specimens are mostly small. Sagittodontina kielcencis disappears at the same horizon. Scabbardella altipes is newcomer at $1379.42 \mathrm{~m}$ i.e. within the uppermost portion of the subzone.

Amorphognathus tvaerensis appears abruptly at $1378.87 \mathrm{~m}$ and immediately after the last record of Pygodus anserinus and Amorphognathus inaequalis. It ranges from the Kriaunos, through the Sartai and into the Vyžūnai formations. Eoplacognathus elongatus occurs together with A. tvaerensis from $1376.50 \mathrm{~m}$ to $1375.02 \mathrm{~m}$. The Amorphognathus tvaerensis Zone extends up to the top of the investigated interval, where the fauna is represented by small non-diagnostic specimens of Amorphognathus.

The Baltoniodus variabilis Subzone is recorded from the base of the Amorphognathus tvaerensis Zone to the FAD of Baltoniodus gerdae at 1374.13 m. Eoplacognathus elongatus is constrained to this subzone. The FAD of Baltoniodus gerdae is at $1374.13 \mathrm{~m}$ and LAD is at 1372.31 
$\mathrm{m}$. The FAD of $B$. gerdae is abrupt and is associated with morphological changes of Amorphognathus tvaerensis holodontiform elements (Fig. 3Q, R). The change is closely tied with the Kriaunos and the Sartai formational boundary, marked by the prominent series of discontinuity surfaces. The Baltoniodus alobatus Subzone begins at $1371.13 \mathrm{~m}$ in the Šventupys Formation. Baltoniodus alobatus stratigraphically replaces Baltoniodus gerdae within the Sartai Formation and LAD of Baltoniodus alobatus is at $1370.05 \mathrm{~m}$. The conodont fauna from the uppermost portion of the Šventupys Formation is low diverse and low yielding. Only few nondiagnostic conodonts have been recovered and the long-range genus Panderodus sp. is relatively the most frequent taxon.

The conodont succession recorded from the Bliudziai-150 core section is comparable with those previously known from Sweden (Bergström 1971, 2007), Estonia (Viira 2008, 2011; Viira et al. 2006; Hints et al. 2012), western Ukraine (Saadre et al. 2004) and Holy Cross Mountain, Poland (Dzik 1994).

\section{The key chitinozoans and Baltoscandian Regional chronostratigraphy in the Bliudziai-150 core}

LASNAMÄGI STAGE: Because the lower part of the Lasnamägi Stage consists of red-coloured carbonates, where organic matter is not preserved, no sampling was carried out here.

The grey limestone yielded the chitinozoan assemblage Laufeldochitina striata, Tanuchitina tallinnensis, Cyathochitina sebyensis and Belonechitina pellifera, which are diagnostic for the Lasnamägi Stage. 
UHAKU STAGE: The lower half of the Uhaku Stage is developed as red limestone without chitinozoans and other organic-walled microfossils. Belonechitina pellifera can be a promising candidate for establishing the Lasnamägi/Uhaku stage boundary as the LAD of $B$. pellifera has been recorded in the bed-by-bed sampled Uuga and Osmussaar sections of NW Estonia just below the boundary of this stage (Uuga cliff, Tammekänd et al. 2010, fig. 5; Osmussaar cliff, Hints et al. 2012, fig. 3). Characteristic of the late Uhaku Stage is the LAD of Laufeldochitina striata and the FAD of Laufeldochitina stentor in the next sample above (Nõlvak and Bauert 2006, appendix 9).

KUKRUSE STAGE: The Uhaku/Kukruse stage boundary was determined in the Bliudziai-150 drillcore by the FAD of Eisenackitina rhenana, which is suggested as a boundary index species by Hints et al. (2007). E. rhenana, Belonechitina intonsa, Conochitina savalaensis, C. viruana, C. tigrina and Laufeldochitina aff. striata are all known to occur in the sedimentary rocks of the Kukruse Stage of Baltoscandia. The well-defined, short-ranged chitinozoan species of the Kukruse age recorded in the Bliudziai-150 drillcore are C. savalaensis, B. intonsa, C. viruana, L. aff. striata and C. tigrina, while E. rhenana and L. stentor have been found in most samples of the Kukruse age.

A similar distribution pattern of key chitinozoan species can be seen in the studied Kerguta-565 and Savala drillcore sections in central and NE Estonia as well (Nõlvak \& Bauert 2015, fig. 1).

HALJALA STAGE: The Kukruse/Haljala stage boundary is easily recognizable by the FAD of several new chitinozoan species in the early Haljala, including Armoricochitina granulifera, 
Angochitina curvata and Lagenochitina dalbyensis. In addition to the short-ranged key chitinozoan species, Cyathochitina giraffa straddles the boundary interval. The key chitinozoan species Belonechitina jaanussonii and B. hirsuta are constrained to the Haljala Stage and can also be used to trace the Kukruse/Haljala stage boundary. The FAD of the key chitinozoan species Spinachitina cervicornis, Desmochitina juglandiformis and D. nodosa are restricted to the Haljala Stage. The $S$. cervicornis Zone extends to the Oandu Stage (Nõlvak \& Grahn 1993, fig. 6). However, the uppermost part of the studied section most likely belongs to the Haljala Stage.

In general the key chitinozoan species distribution in the Haljala Stage of the Bliudziai150 drillcore matches well with reported data from Vasknarva-639, Piilsi-729 and Kerguta-565 drillcore sections in central Estonia (Bauert et al. 2014).

\section{Correlation of chitinozoan and conodont zones}

The ties of the chitinozoan and conodont successions from the Bliudziai-150 core is shown in Figure 1 and briefly outlined here. The Laufeldochitina striata chitinozoan Zone (Lasnamägi to Uhaku stages) comprises the Pygodus serra Zone and Sagittodontina kielcensis Subzone of the Pygodus anserinus Zone. The Laufeldochitina stentor Zone (uppermost Uhaku to uppermost Kukruse) initiates in the uppermost part of the Pygodus anserinus Zone and includes the Baltoniodus variabilis Subzone of the Amorphognathus tvaerensis Zone. The base of the Haljala Stage marks an onset of transgression in the Baltoscandian basin and the FAD of Angochitina curvata, Armoricochitina granulifera and Lagenochitina dalbyensis all from the Haljala Stage match with the appearance of Baltoniodus gerdae and the chitinozoan taxa are constrained to the Baltoniodus gerdae conodont Subzone. The younger Belonechitina hirsuta and Spinachitina 
cervicornis zones are constrained to the Baltoniodus alobatus Subzone of the Amorphognathus tvaerensis Zone.

The chitinozoan and conodont biozones in the Bl-150 core correspond to those already known from the Baltoscandian region and thus correlate easily with existing biostratigraphic chitinozoan and conodont zonations of the region (i.e. Bergström 1971, 1983, 2007a, b; Grahn and Nolvak 2010).

The Sandbian chitinozoan association from B1-150 has been recorded also from the Welsh and Shelve Inlier, UK (Vandebroucke 2008; Vandebroucke et al. 2009). International correlation of the conodont zones to e.g. South China, Precordilleran Argentina and eastern North America was outlined recently by Bergström (2007b).

The FAD of Eisenackitina rhenana is regarded an important proxy for the Upper Ordovician series boundary (and Darriwilian/Sandbian stage boundary) and was recorded at the base of global Upper Ordovician Series in the Fågelsång GSSP section, Sweden (Bergström et al. 2001; Vandebroucke 2004). In addition, E. rhenana was also recorded in several samples straddling the Middle to Upper Ordovician series boundary in the Lower Wood Brook and Spy Wood Brook sections of the Shelve Inlier, UK (Vandenbroucke et al. 2009), thus enabling a good biostratigraphic correlation of the lower Sandbian successions between Wales and Baltoscandia (see also Vandenbroucke 2008). In the Bl-150 core, E. rhenana appears at $1380.0 \mathrm{~m}$ within the Laufeldochitina stentor Zone. This level is placed within the Amorphognathus inaequalis conodont Subzone of the Pygodus anserinus Zone (Fig. 1), which is in accordance with the base of the international Upper Ordovician Series (or the Sandbian Stage) in the GSSP section at Fågelsång, Sweden (i.e. Bergström (2007a). 


\section{Summary}

The common occurrence of chitinozons and conodonts from the detailed study of the BL-150 core are presented as collation of the two biozonations (Fig. 1). The chitinozoan and conodont successions in the Bl-150 well, Lithuania, are nearly identical to those of previously described localities of the Baltocandian region (e.g. Hints et al. 2012). Conodonts allow correlation to the Mójcza Limestone, Holy Cross Mountains, Poland (Dzik 1994), as well as to other localities worldwide (e.g. Bergström 2007b), while chitinozoans permit correlation to several localities in UK.

The appearance of several key chitinozoan species (Armoricochitina granulifera, Angochitina curvata, Lagenochitina dalbyensis) as well as the conodont species Baltoniodus gerdae, coincides closely with the Kukruse-Haljala regional stages boundary (1373.90 m) and represents the start of the Kegel depositional sequence (e.g. Dronov and Holmer 1999; Dronov and Rozhnov 2007). In the Bl-150 well the first occurrence of Eisenackitina rhenana at $1380.00 \mathrm{~m}$ allows for the recognition of the base of the International Upper Ordovician Series (= Sandbian Stage) in carbonate facies.

\section{Acknowledgements}

The paper is a contribution to the IGCP 591. Financial support to Svend Stouge and Jan A. Rasmussen by a grant from Geocenter Denmark, Copenhagen, Denmark is greatly appreciated. Jaak Nõlvak received support from the Estonian Research Council grants PUT378 and ETF9039. 
The journals referees Guillermo L. Albanesi and Thijs Vandenbroucke are gratefully acknowledged for their constructive reviews. We also appreciate the comments and proposals made to the text by the editor Mike Melchin.

\section{References}

Bauert, G., Nõlvak, J. and Bauert, H. 2014. Chitinozoan biostratigraphy in the Haljala Regional Stage, Upper Ordovician: a high-resolution approach from NE Estonia. GFF, 136: 2629.

Bergström, S. M. 1971. Conodont biostratigraphy of the Middle and Upper Ordovician of Europe and Eastern North America. Geological Society of America, Memoir, 127: 83-157.

Bergström, S. M. 1983. Biogeography, evolutionary relationships, and biostratigraphic significance of Ordovician platform conodonts. Fossils and Strata, 15: 35-58.

Bergström, S. M. 2007a. Middle and Upper Ordovician conodonts from the Fågelsång GSSP, Scania, southern Sweden. GFF, 129: 77-82.

Bergström, S. M. 2007b. The Ordovician conodont biostratigraphy of the Siljan region, southcentral Sweden: a brief review of an international reference standard. Sveriges Geologiska Undersökning, Rapporter och Meddelanden, 128: 26-41.

Dronov, A.V. and Holmer L. E. 1999: Depositional sequences in the Ordovician of Baltoscandia. 
In: Kraft P. Fatka, O. (eds). Quo vadis Ordovician? Acta Universitis Carolinae, geologica, 43, (1/2): 133-136.

Dronov, A. and Rozhnov S. 2007. Climatic changes in the Baltoscandian basin during the

Ordovician: sedimentological and palaeontological aspects. Acta Palaeontologica Sinica, 46: 108-113.

Dzik, J. 1978. Conodont biostratigraphy and paleogeographical relations of the Ordovician Mójcza Limestone (Holy Cross mountains, Poland). Acta Palaeontologica Polonica, 23: $51-72$.

Dzik, J. 1994. Conodonts of the Mójcza Limestone. Palaeontologia Polonica, 53: 43-128.

Epstein, A. G., Epstein, J. B. \& Harris, L. D. 1977. Conodont color alteration - an index to organic metamorphism. U.S. Geological Survey Professional Paper, 995: 1-27.

Grahn, Y. 1984. Ordovician Chitinozoa from Tallinn, northern Estonia. Review of Palaeobotany and Palynology, 43: 5-31.

Grahn, Y., and Nõlvak, J. 2010. Swedish Ordovician Chitinozoa and biostratigraphy: a review and new data. Palaeontographica Abteilung B: 5-71.

Hints, O., Nõlvak, J., and Viira, V. 2007. Age of Estonian kukersite oil shale - Middle or Late Ordovician? Oil Shale, 24, (4): 527-533.

Hints, O., Viira, V. and Nõlvak, J. 2012. Darriwilian (Middle Ordovician) conodont 
biostratigraphy in NW Estonia. Estonian Journal of Earth Sciences, 61, (4): 210-226.

Jaanusson. V. 1976. Faunal dynamics in the Middle Ordovician (Viruan) of Balto-Scandia. In The Ordovician System: proceedings of a Palaeontological Association Symposium, Birmingham, September 1974. Edited by M. G. Bassett. University of Wales Press and National Museum of Wales, Cardiff: 301-326.

Laskov, E.M., Visnjakov, I. B., Glusko, V. V. Drumja, A.V., Zinovenko, G.V., Kala, E.A., Njaga, V.I., Omeljanenko, A.A., Piskun, A.A., Pomjanovskaja, G.M., Puskin, V.I., Ulst, R.Z., Chizniakov, A.V. 1981. Grundzüge der tectonischen bewegungen und der Sedimentation wärend des Ordoviziums am SW - Rand der Osteuropäischen Tafel (Anteil UdSSR). Zeitschrift für angewande Geologie, 27, (4): 177-180.

Laskovas, J. 2000. The sedimentation environments of the Ordovician basin in the south-western margin of the East European Platform and lithogenesis of deposits. Geologijos institutas, Vilnius, 314 pp. (in Russian with English summary).

Männik, P. and Viira, V. 2012. Ordovician conodont diversity in northern Baltic. Estonian Journal of Earth Sciences, 61: 1-14.

Nõlvak, J. and Grahn, Y. 1993. Ordovician chitinozoan zones from Baltoscandia. Review of Palaeobotany and Palynology, 79: 245-269.

Nõlvak, J. and Bauert, G. 2006. Distribution of Ordovician chitinozoans. In Kerguta (565) Drill Core. Edited by A. Põldvere, Estonian Geological Sections, 7: 9-11.

Nõlvak, J. and Bauert, G. 2015. New biostratigraphically important chitinozoans from the 
Kukruse Regional Stage, Upper Ordovician of Baltoscandia. Estonian Journal of Earth Sciences, 64, (3), 218-224.

Nõlvak, J., Grahn, Y., and Sturkell, E. F. F. 1999. Chitinozoan biostratigraphy of the Middle Ordovician Dalby Limestone in the Fjäcka section, Siljan District, Sweden. Proceedings of the Estonian Academy of Sciences, Geology, 48, (2): 75-85.

Paris, F., Grahn, Y., Nestor, V., and Lakova, I. 1999. A revised chitinozoan classification. Journal of Paleontology , 73, (4): 549-570.

Saadre, T., Einasto, R., Nõlvak, J., and Stouge, S. 2004. Ordovician stratigraphy of the Kovel-1 well (Volkhov-Haljala) in the Volynia region, northwestern Ukraine. Bulletin of the Geological Survey of Denmark, 51: 47-69.

Tammekänd, M., Hints, O., and Nõlvak, J. 2010. Chitinozoan dynamics and biostratigraphy in the Väo Formation (Darriwilian) of the Uuga Cliff, Pakri Peninsula, NW Estonia. Estonian Journal of Earth Sciences, 59, (1): 25-36.

Vandenbroucke, T. 2004. Chitinozoan biostratigraphy of the Upper Ordovician Fågelsång GSSP, Scania, southern Sweden. Review of Palaeobotany and Palynology, 130: 217-239.

Vandenbroucke, T.R.A. 2008. An Upper Ordovician chitinozoan biozonation in British Avalonia (England and Wales). Lethaia, 41: 275-294.

Vandenbroucke, T.R., Ancilletta, A., Fortey, R.A. and Verniers, J. 2009. A modern assessment of 
Ordovician chitinozoans from the Shelve and Caradoc areas, Shropshire, and their significance for correlation. Geological Magazine, 146: 216-236.

Viira, V. 2008. Conodont biostratigraphy in the Middle-Upper Ordovician boundary beds of Estonia. Estonian Journal of Earth Sciences, 57, (1): 23-38.

Viira, V. 2011. Lower and Middle Ordovician conodonts from the subsurface of SE Estonia and adjacent Russi. Estonian Journal of Earth Sciences, 60, (1): 1-21.

Viira, V., Aldridge, R.J., and Curtis, S. 2006. Conodonts of the Kiviõli Member, Viivikonna Formation (Upper Ordovician) in the Kohtla section, Estonia. Proceedings of the Estonian Academy of Sciences Geology, 55, (3): 213-240.

Zhang, J. 1998. Conodonts from the Guniutan Formation (Llanvirnian) in Hubei and Hunan Provinces, south-central China. Stockholm Contributions in Geology, 46: 1-161.

\section{FIGURE CAPTIONS}

Figure 1. The Ordovician succession of the BL-150 well and ranges of selected chitinozoan and conodont species for the upper Darriwilian - lower Sandbian succession. Inserted figure shows the Baltoscandian region and the location of the Bliudziai-150 well in southern Lithuania; the general outline of the 'confacies belts' (Jaanusson 1976) is indicated.

Figure 2. Illustration of selected chitinozoan species in the Bliudziai-150 core.

Dimensions (vesicle length $\mathrm{x}$ maximal diameter) are in $\mu \mathrm{m}$. Scale bar is $100 \mu \mathrm{m}$ for all images. 
(A) Laufeldochitina aff. striata, GIT 726-1, sample 1376.35-1376.50 m, 1127x139. (B) Tanuchitina tallinensis, GIT 726-2, sample 1389.35-1389.54 m, 1023x103. (C) Conochitina tigrina, GIT 726-3, sample 1373.90-1374.19 m, 564x102. (D) Belonechitina pellifera, GIT 726-4, sample 1388.79-1389.00 m, 149x64. (E) Belonechitina intonsa, GIT 726-5, sample 1378.62-1378.87 m, 177x70. (F) Desmochitina juglandiformis, GIT 726-6, sample 1370.36-1370.59 m, 114x93. (G) Angochitina curvata, GIT 726-7, sample 1373.54-1373.90 m, 229x61. (H) Armoricochitina granulifera, GIT 726-8, sample 1373.54-1373.90 m, 232x118. (I) Belonechitina jaanussonii, GIT 726-9, sample 1372.51-1372.79 m, 368x81. (J) Cyathochitina giraffa, GIT 726-10, sample 1373.32-1373.54 m, 347x209.

Figure 3. Scanning microscope images of upper Middle and lower Upper Ordovician conodonts from the Bliudziai-150 core. Scale bars represent $100 \mu \mathrm{m}$.

(A, B) Baltoniodus prevariabilis (Fåhræus). (A) Pa element, lateral view, sample 1390.92-1390.72 m, MGUH 32429. (B) Pb element, lateral view, sample 1390.92-1390.72 m, MGUH 31430. (C, D) Baltoplacognathus reclinatus (Fåhræus). (C) Sinistral pastiniplanate $\mathrm{Pb}$ element,upper view, sample 1389.54-1389.35 m, MGUH 31431. (D) Dextral stelliplanate Pa element, upper view, sample 1389.54-1389.35 m, MGUH 31432. (E, J, K, Q, R) Amorphognathus tvaerensis Bergström. (E) Pb element, outer lateral view, sample 1378.87-1378.62 m, MGUH 31433. (J) Pa element, upper view, sample 1378.87-1378.62 m, MGUH 31434. (K) Pb element, outer lateral view, sample 1378.87-1378.62 m, MGUH 31435. (Q) Geniticulate (holodontiform) M element with large reclined cusp, lateral view, sample 1376.50-1376.35 m, MGUH 31436. (R) Geniculate (holodontiform) M element with large anterior denticles, sample 1376.50-1376.35 m, MGUH 31437. (F, G) Baltoniodus variabilis (Bergström). (F) Pa element, outer lateral view, sample 1378.87-1378.62 m, MGUH 31438. (G) Pa element, inner lateral view, sample 1378.87-1378.62 
m, MGUH 31439. (H, I) Baltoplacognathus robustus (Bergström). (H) Dextral pastiniplanate Pb element, upper view, sample 1386.67-1386.50 m. MGUH 31440. (I) Dextral stelliplanate Pa element, upper view, sample 1385.17-1384.98m, MGUH 31441. (L, M) Baltoniodus gerdae (Bergström). (L) Pa element, outer view, sample 1373.08-1372.93 m, MGUH 31442. (M) Pb element, inner lateral view, sample 1373.08-1372.93 m, MGUH 31443. (N-P) Eoplacognathus lindstroemi. (N) Dextral pastiniplanate Pb element, upper view, sample 1383.15-1383.02 m, MGUH 31444. (O) Dextral stelliplanate Pa element, upper view, sample 1383.15-1383.02 m, MGUH 31445. (P) Sinistral stelliplanate Pa element, upper view, sample 1383.15-1383.02 m, MGUH 31446. (S, T) Pygodus serra (Hadding). (S) Pa (pygodiform) element, upper view, sample 1389.00-1388.79 m, MGUH 31447. (T) Pb (haddingodiform) element, lateral view, sample 1388.40-1388.12 m, MGUH 31448. (U, V) Pygodus anserinus Lamont and Lindström. (U) Pa (pygodiform) element, upper view, sample 1384.79-1384.55 m, MGUH 31449. (V) Pb (haddingodiform) element, lateral view, sample 1384.79-1384.55 m, MGUH 31450. (X, Y) Eoplacognathus elongatus (Bergström). (X) Dextral pastiniplanate $\mathrm{Pb}$ element, upper view, sample 1377.53-1377.43 m, MGUH 31451. (Y) Sinistral stelliplanate Pa element, upper view, sample 1377.53-1377.43 m, MGUH 31452. (Z) Scabbardella altipes (Hennigsmoen). Lateral view, sample 1379.37-1379.22 m, MGUH 31453. 


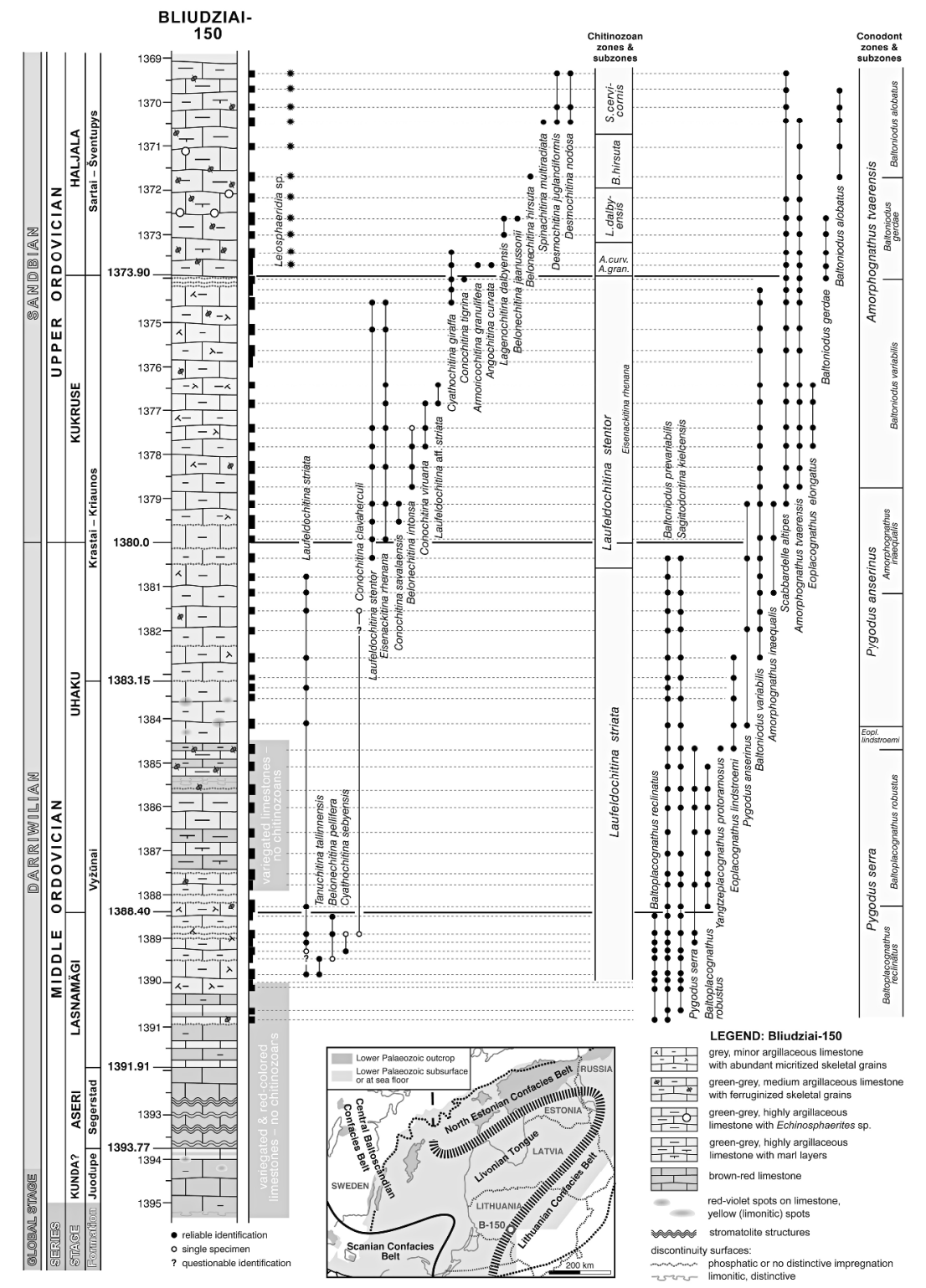

The Ordovician succession of the BL-150 well and ranges of selected chitinozoan and conodont species for the upper Darriwilian - lower Sandbian succession. Inserted figure shows the Baltoscandian region and the location of the Bliudziai-150 well in southern Lithuania; the general outline of the 'confacies belts'

(Jaanusson 1976) is indicated.

$297 \times 420 \mathrm{~mm}(300 \times 300$ DPI $)$ 


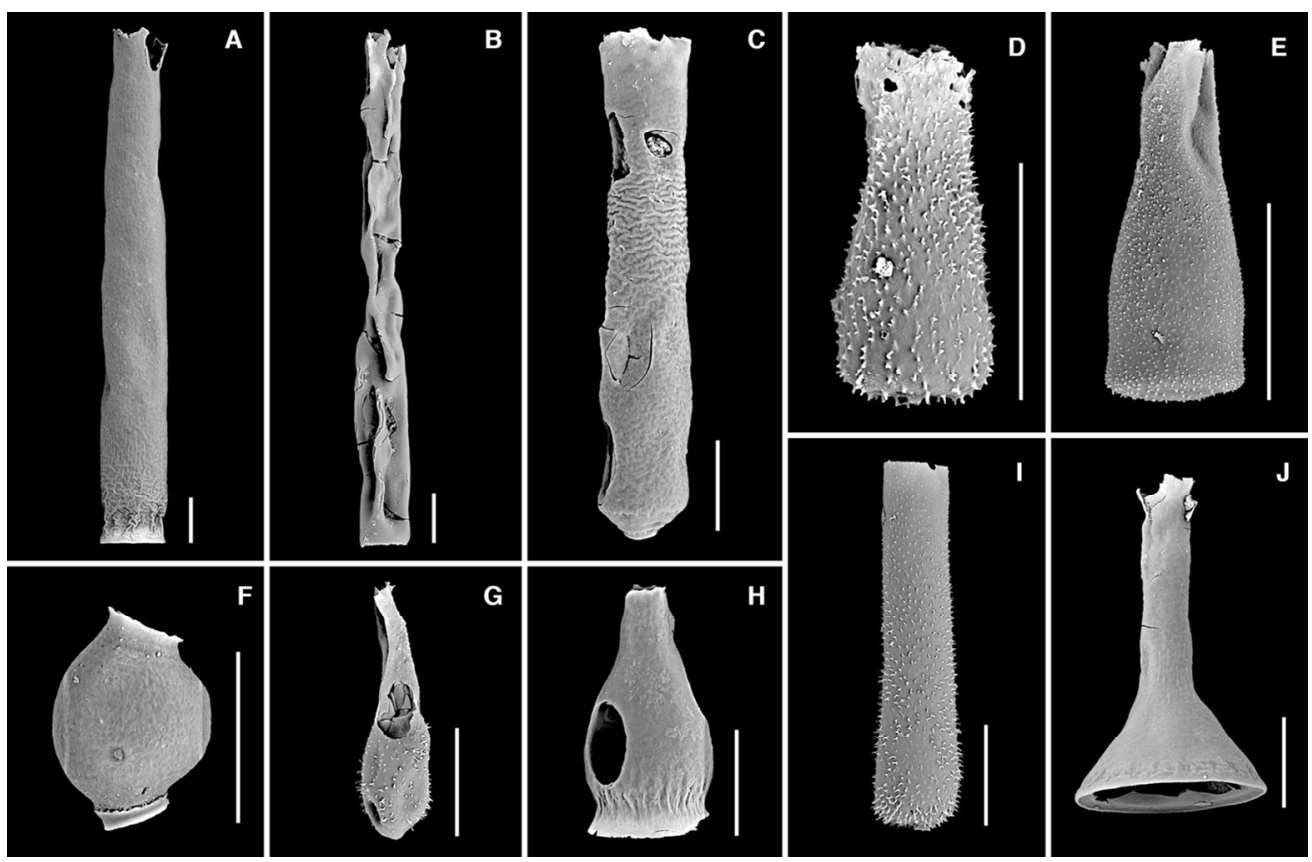

Illustration of selected chitinozoan species in the Bliudziai-150 core.

Dimensions (vesicle length $x$ maximal diameter) are in $\mu \mathrm{m}$. Scale bar is $100 \mu \mathrm{m}$ for all images.

(A) Laufeldochitina aff. striata, GIT 726-1, sample 1376.35-1376.50 m, 1127x139. (B) Tanuchitina tallinensis, GIT 726-2, sample 1389.35-1389.54 m, 1023x103. (C) Conochitina tigrina, GIT 726-3, sample 1373.90-1374.19 m, 564x102. (D) Belonechitina pellifera, GIT 726-4, sample 1388.79-1389.00 m, $149 \times 64$.

(E) Belonechitina intonsa, GIT 726-5, sample 1378.62-1378.87 m, 177x70. (F) Desmochitina

juglandiformis, GIT 726-6, sample 1370.36-1370.59 m, 114x93. (G) Angochitina curvata, GIT 726-7, sample 1373.54-1373.90 m, 229x61. (H) Armoricochitina granulifera, GIT 726-8, sample 1373.54-1373.90

m, 232x118. (I) Belonechitina jaanussonii, GIT 726-9, sample 1372.51-1372.79 m, 368x81. (J) Cyathochitina giraffa, GIT 726-10, sample 1373.32-1373.54 m, 347x209.

$117 \times 76 \mathrm{~mm}(300 \times 300$ DPI $)$ 


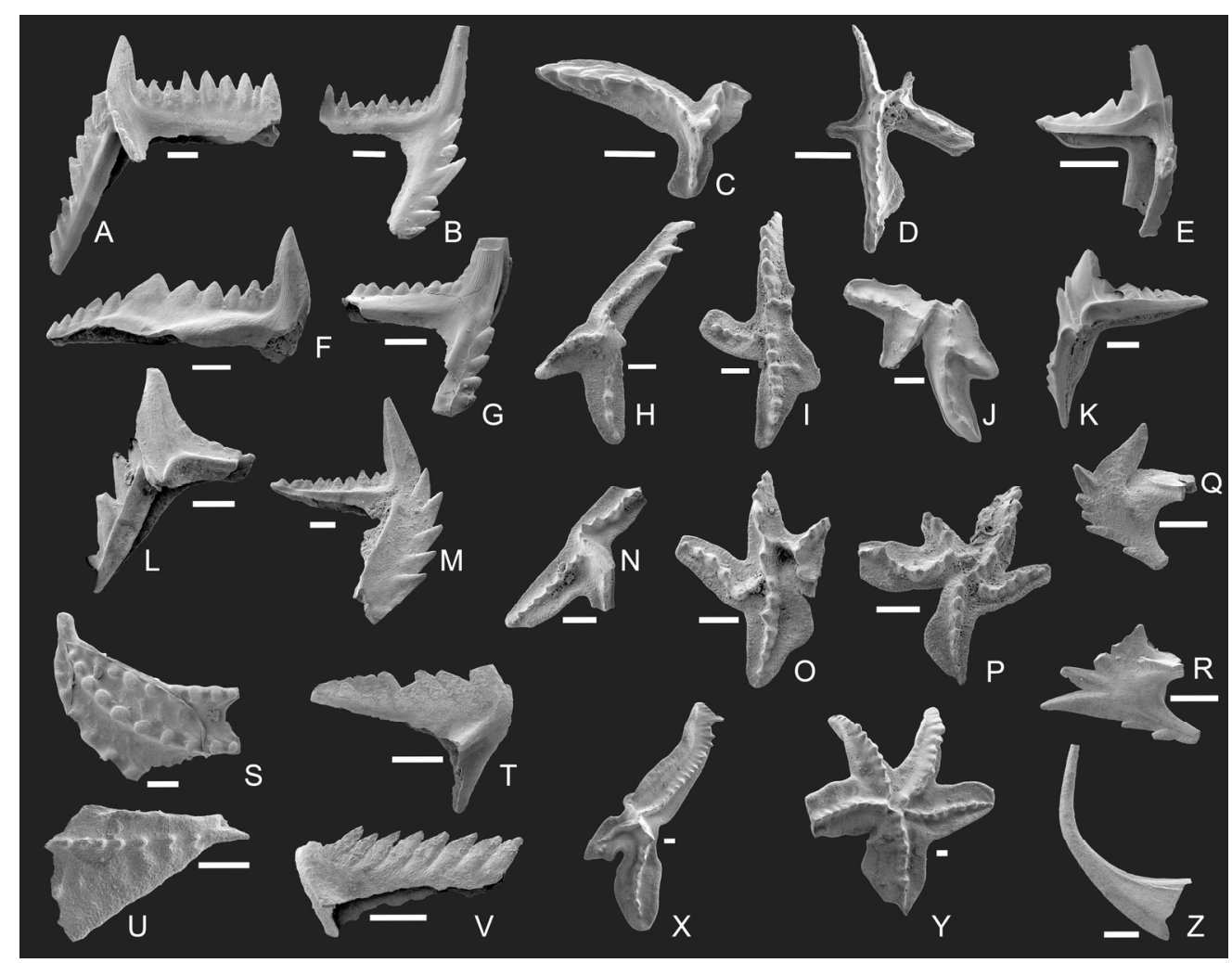

Scanning microscope images of upper Middle and lower Upper Ordovician conodonts from the Bliudziai-150 core. Scale bars represent $100 \mu \mathrm{m}$.

(A, B) Baltoniodus prevariabilis (Fåhræus). (A) Pa element, lateral view, sample 1390.92-1390.72 m, MGUH 32429. (B) Pb element, lateral view, sample 1390.92-1390.72 m, MGUH 31430. (C, D) Baltoplacognathus reclinatus (Fåhræus). (C) Sinistral pastiniplanate Pb element, upper view, sample 1389.54-1389.35 m, MGUH 31431. (D) Dextral stelliplanate Pa element, upper view, sample 1389.54-1389.35 m, MGUH 31432. $(E, J, K, Q, R)$ Amorphognathus tvaerensis Bergström. (E) Pb element, outer lateral view, sample 1378.871378.62 m, MGUH 31433. (J) Pa element, upper view, sample 1378.87-1378.62 m, MGUH 31434. (K) Pb element, outer lateral view, sample 1378.87-1378.62 m, MGUH 31435. (Q) Geniticulate (holodontiform) M element with large reclined cusp, lateral view, sample 1376.50-1376.35 m, MGUH 31436. (R) Geniculate (holodontiform) M element with large anterior denticles, sample 1376.50-1376.35 m, MGUH 31437. (F, G) Baltoniodus variabilis (Bergström). (F) Pa element, outer lateral view, sample 1378.87-1378.62 m, MGUH 31438. (G) Pa element, inner lateral view, sample 1378.87-1378.62 m, MGUH 31439. (H, I)

Baltoplacognathus robustus (Bergström). (H) Dextral pastiniplanate $\mathrm{Pb}$ element, upper view, sample 1386.67-1386.50 m. MGUH 31440. (I) Dextral stelliplanate Pa element, upper view, sample 1385.171384.98m, MGUH 31441. (L, M) Baltoniodus gerdae (Bergström). (L) Pa element, outer view, sample 1373.08-1372.93 m, MGUH 31442. (M) Pb element, inner lateral view, sample 1373.08-1372.93 m, MGUH 31443. (N-P) Eoplacognathus lindstroemi. (N) Dextral pastiniplanate Pb element, upper view, sample 1383.15-1383.02 m, MGUH 31444. (O) Dextral stelliplanate Pa element, upper view, sample 1383.151383.02 m, MGUH 31445. (P) Sinistral stelliplanate Pa element, upper view, sample 1383.15-1383.02 m, MGUH 31446. (S, T) Pygodus serra (Hadding). (S) Pa (pygodiform) element, upper view, sample 1389.001388.79 m, MGUH 31447. (T) Pb (haddingodiform) element, lateral view, sample 1388.40-1388.12 m, MGUH 31448. (U, V) Pygodus anserinus Lamont and Lindström. (U) Pa (pygodiform) element, upper view, sample 1384.79-1384.55 m, MGUH 31449. (V) Pb (haddingodiform) element, lateral view, sample 1384.791384.55 m, MGUH 31450. (X, Y) Eoplacognathus elongatus (Bergström). (X) Dextral pastiniplanate Pb element, upper view, sample 1377.53-1377.43 m, MGUH 31451. (Y) Sinistral stelliplanate Pa element, upper view, sample 1377.53-1377.43 m, MGUH 31452. (Z) Scabbardella altipes (Hennigsmoen). Lateral view, sample 1379.37-1379.22 m, MGUH 31453. 
$160 \times 124 \mathrm{~mm}(300 \times 300 \mathrm{DPI})$ 